\title{
The Concept of Genius Loci in Relation to Landscape Changes
}

\author{
Alexandru CIOBOTA ${ }^{1)}$, Miroslava SLIACKA ${ }^{2)}$, Vladimir OBRADOVICI ${ }^{11}$ \\ ${ }^{1)}$ Faculty of Architecture, "Polytechnic" University of Timisoara, Bulevardul Vasile Parvan 2, Timisoara \\ 300223, Romania; \\ ${ }^{2)}$ Faculty of Horticulture, Mendel University in Brno, Valtická 337 / 69144 Lednice, Czech Republic; \\ ${ }^{*}$ Corresponding author, e-mail: alciobota@yahoo.com
}

Bulletin UASVM Horticulture 72(1) / 2015

Print ISSN 1843-5254, Electronic ISSN 1843-5394

DOI:10.15835/buasvmen-hort:10529

\begin{abstract}
This paper shoes that a phenomenological analysis can be a holistic way of understanding the Genius loci of the cultural heritage, thus the premise for consciously intervening in such a context. For this reason we have chosen two case studies, two small Czech villages in the mountains of the Banat region (Ravensca and Garnic) which are further analyzed in comparison for a better understanding of their features. We have exemplified an interdisciplinary analysis of some particular aspects of their environment, through the point of view of the landscape architect, the urbanist and the architect. The results show that a phenomenological understanding of a specific context can produce useful tools in improving the present regulations concerning landscape, urban and architectural design within cultural heritage sites.
\end{abstract}

Keywords: community, Genius loci, landscape, cultural heritage.

\section{INTRODUCTION}

1. A phenomenological perspective on the built universe. The Czech colonists in Banat. From a phenomenological point of view, the way that the environment is shaped is the result of its inner reality and the complex causes and effects, in time, that precede the present. We try to understand the Czech environment as a result of an overlay between a particular culture that was part of a historical, political, social, cultural and spiritual context and a natural environment with its particular individuality. As Romanian poet and philosopher Lucian Blaga explains in his essay (1969) it is not only the natural environment which influences the culture (man) inhabiting a specific place, but also the human being itself who projects and embodies its interior patterns on nature. Landscape design, architecture and the morphology of the habitat can be seen as a transformed (reshaped) nature. Eliade wrote that "the man of traditional societies is admittedly a homo religious, but his behavior forms a part of the general behavior of mankind and thus is of concern to philosophical anthropology, to phenomenology, to psychology" (Eliade, 1956).

On the other hand, Norberg Schultz places the human being between Heaven and Earth: "As has already been pointed out, the sky offers the abstract form, whereas the earth offers the concrete materials and elements which serve to give the cosmic order presence." (Norberg-Schulz, 1986). In his view Heaven symbolizes the Divine, the timeless, the intangible and human aspiration; Earth symbolizes the Created Universe (to which the man belongs), the temporal, the immediate and the particular, and nature, subject to transformation and death from which the man needs to transcend to his original Divine status. Man exists between Earth and Heaven. Norberg Schultz thus explains Islamic architecture and its urban morphologies as a result of the Islamic Religion on the one hand and the particular relationship between Sky and 
Sand in which this culture was formed on the other hand. As previously stated, the Czech villages from Banat highlands can be understood as a result of the interaction between a specific culture (the Czech colonists) with its specific interior patterns, part of a specific historical moment (the Habsburg monarchy colonization) and a particular natural environment (Banat, Almajului mountains, partially inhabited by native Romanian villagers). Thus, he way we see the landscape today is also a result of the process of time and of the inner context transformations from the beginning of the settlement until now.

We will try to describe the way the colonist's cultural interior patterns were overlaid on the natural environment and how the two realities transformed and influenced each other, by studying certain aspects of the settlement morphology and the homestead architecture. Landscape (and in particular cultural landscape) could be also considered the place where the past and the present are facing each other (Lowenthal, 1979). Being under continuous change, it is very important to discover the landscape specific features that could be transmitted to future generations. Those features represent the identity of a community and should be seen as part of its Genius loci.

2. History of Czech villages in Romanian Banat. It is so far known that the colonization of the Czech population by the Habsburg Monarchy was done gradually during the $19^{\text {th }}$ century, in 3 waves. The first wave of settlers came to this area during the years 1823-1825 and the villages Saint Helena and Saint Elizabeth were based. The second wave of settlers arrived during the years 1827-1828 while the colonization was organized by the military authorities, and aimed to guard the borders. During this period, several other Czech villages were based: Bigar (Bigras), Eibenthal, Ravensca (Rovensko), Sumita (Šumice) and the largest Czech village Garnic (Gernik), as well as the Frauenwiese village (Frauvízn, Poiana Muierii) which disappeared in the 1860's. A gradual increase in the village population could be seen throughout time and until the economic crisis started, period which was followed by a decrease in population and mass emigration to Czechoslovakia. After World War II, the Czechoslovak government allowed the people from Banat villages to return to their homeland.
After 1989, due to the economical and political instability in Romania, other inhabitants from the Czech villages in Banat emigrated in order to find work abroad, most of them settling in the Czech Republic. Currently, Garnic has 340 inhabitants left, while Ravensca has 70.

\section{MATERIALS AND METHODS}

As the European Rural Heritage Observation Guide states: "No heritage element can be understood in isolation" (CEMAT, 2003). Moreover, the UNESCO Recommendation on the Historic Urban Landscape (UNESCO, 2011) states: " urban area understood as the result of a historic layering of cultural and natural values and attributes, extending beyond the notion of "historic centre" or "ensemble" to include the broader urban context and its geographical setting". We focused our research on the two Czech villages on the relationship between the geographical/natural context, with a specific culture and complex elements such as architecture and landscape. Patricia M. O'Donnell (2008) considers the cultural landscape to be a result of the interaction between people and place and as a sum of tangible and intangible elements. Norberg Schultz (1980) describes place consisting of: space, a three dimensional perception of elements and character, meaning its atmosphere. While debating on natural and built places, in Genius Loci: Towards a Phenomenology of Architecture, Norberg-Schultz also presents the universal order in which the Earth is a life generating place (Terra Mater) and the Sky, representing Heaven, an untouchable, ideal place. Norberg Schultz's phenomenological philosophy is inspirational for this research.

The research methodology is based on landscape, settlement morphology and architecture analysis and it has different layers of study:

- Interdisciplinary study: on the concept of Genius Loci (Norberg-Schulz, 1980), history of Banat and Banat Czech villages, landscape/urbanism/ architecture, phenomenology, theology;

- Local archives study: The National Archives in Timisoara and Caransebes;

- Interdisciplinary site analysis, several field studies, on several layers and different scales (James, LaGro, 2008; McHarg, 1992; VerschuureStuip, 2009);

- Community interviews. 


\section{RESULTS AND DISCUSSION}

\section{The landscape of Ravensca}

Our debate on the Ravensca landscape will start with a talk about boundaries, a landscape element which, as Norberg Schultz says, represents the "openness" of a man-made landscape. The road that starts to go up from Sopotul Nou to Ravensca crosses a very dense forest which is guarded almost all the way by a creek, reminding one about a very important element of Paradise: water as life generating. At the end of the climb, the Ravensca village is revealed, laying on the top of the hill and spreading on its ridges (Fig.2.1). A very quick look around exposes a paradox: despite the village being surrounded by a dense forest, it is still very open, showing a picturesque view all around and transforming Ravensca into one of the most scenic villages in Banat (Fig. 1).

Those boundaries are only penetrated in a few places by roads that poorly connect Ravensca to other villages and which during winter time are mostly closed. (Fig. 2.2).

Because of the topography, the parcels are very diverse, their form depending on the terrain accidents or on the relation with the forest. Usually they have permeable boundaries, revealing not only the openness of the village to the landscape, but also the openness of the inhabitants to one another, due to the fact that these elements sometimes facilitate a good visual relation between households situated on neighboring hilltops.

The topography of the terrain is very diverse, a succession of hills and valleys generating a series of perspective plans to the horizon. On the other hand, the concept of Earth as a life generator (Tellus Mater) (Norberg Schultz, 1980) gave man the opportunity to understand and act in harmony with nature. That is why one of the principal activities in Ravensca is agriculture, low intensity farming as Baldock defines it (Baldock et. al.,
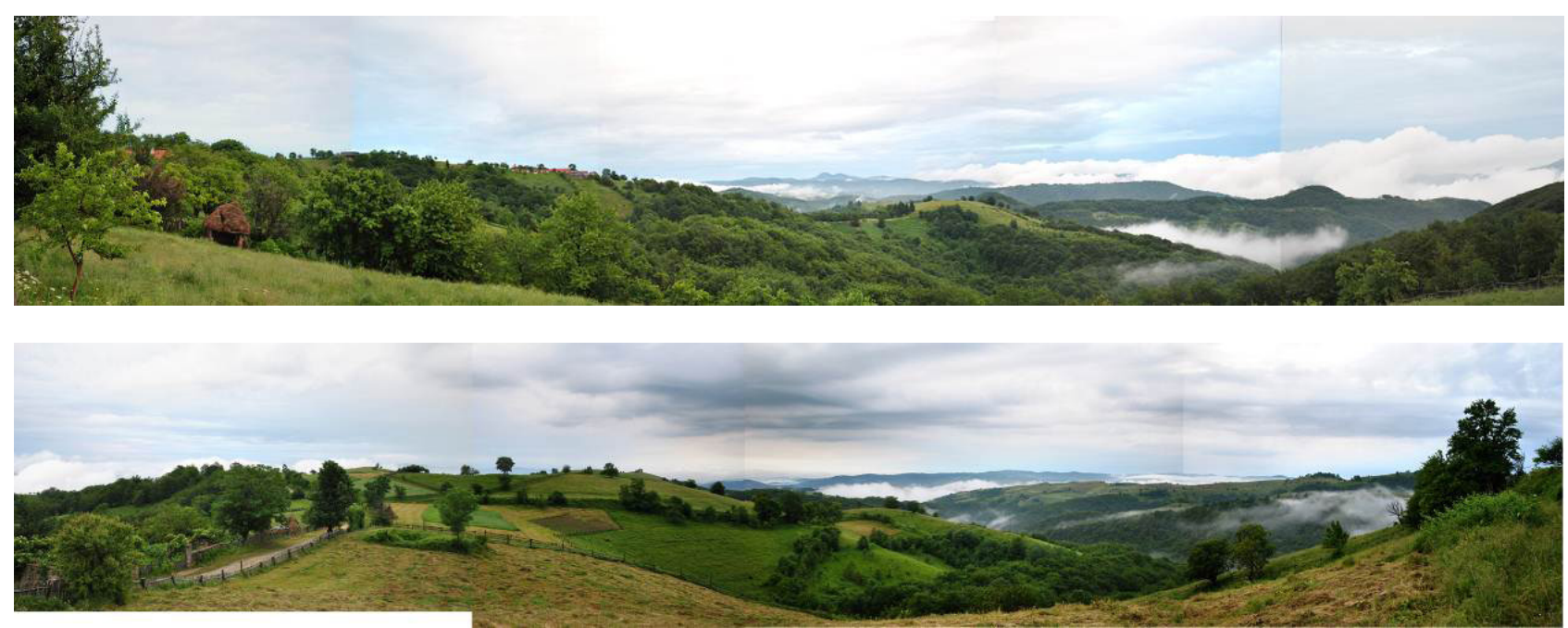

Fig. 1. Different perspective plans and the relation to the sky (original).
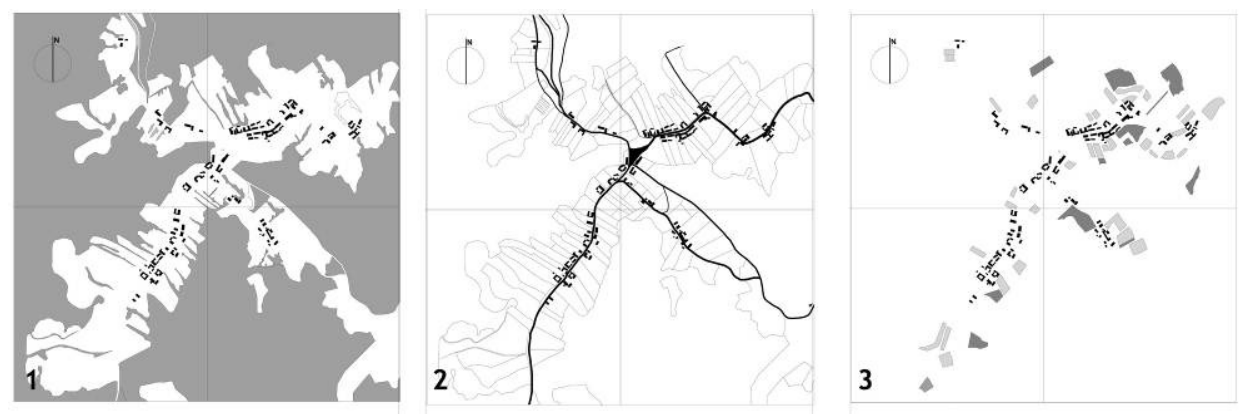

Fig. 2. Ravensca (1) the dense forest as a very strong boundary; (2) penetrations and roads; (3) land use mosaic, agriculture and orchards (original). 
1994), the practice of agroforestry (Workman et. al., 2014; Herzog, 1998) being also typical. Among the agricultural activities, the main occupation is animal breeding, but the community also grows some small gardens for family needs (Fig.2.3). Occasionally, they grow fruit trees combined with meadows, but this is not specific to the Ravensca village. All of these land uses mixed with the terrain's topography determine interesting land mosaics on parcels, which function according to the manner in which the land is farmed (Fig.3). Usually, the plots of land and garden limits consist in vegetation, shrubs mixed with trees and sometimes the forest itself could be the limit.

\section{The landscape in Garnic}

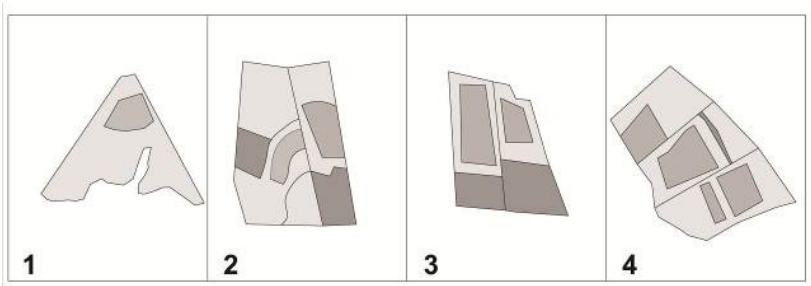

Fig.3. Plot structure and organization (1) mixed agriculture and meadows with forest as a limit; (2) mixed, agriculture, meadows and orchard with terrain worked on slope; (3) valley mixed agriculture with meadows and orchards; (4) mixed agriculture and meadows and occasional delimitations with fruit trees (original).
The beauty of the Garnic village resides in its mystery, a feeling one cannot discover at a glance, but gradually, as you enter deeper into the village life (Fig.4). The village has no strong boundaries and you can feel its openness to the east, towards its hilly and cultivated landscape (Fig.7.1) In contrast, to the west, there is a dense forest. Even so, being located in the valley, the village is protected. The boundaries are penetrated by a wide road, coming from Padina Matei and leading towards Sichevita. The road enters from Padina on the top of the hill, from where the whole surrounding area can be admired and then plunges into the village.

The road enters straight into the village, gradually becoming very labyrinthine and splitting into many smaller roads which get lost in the settlement's structure (Fig.7.2). A plus of mystery is added by the occurrence of water, a small spring somewhere in the middle of the village, which "feeds" the mills' need of water. The mystery is accentuated due to the relation with the sky, which changes gradually from a generous perspective to the horizon, to a very narrow perspective in the valley. The light completes this entire scenario (Fig.5), creating a great atmosphere, in relation to architecture and landscape.

The whole structure of the village relates to landscape, topography, water, natural vegetation and the forest, transforming the urban tissue into a labyrinth. This labyrinthine structure sometimes reveals community gathering points/spaces, such as the square near the church, the calvarium on

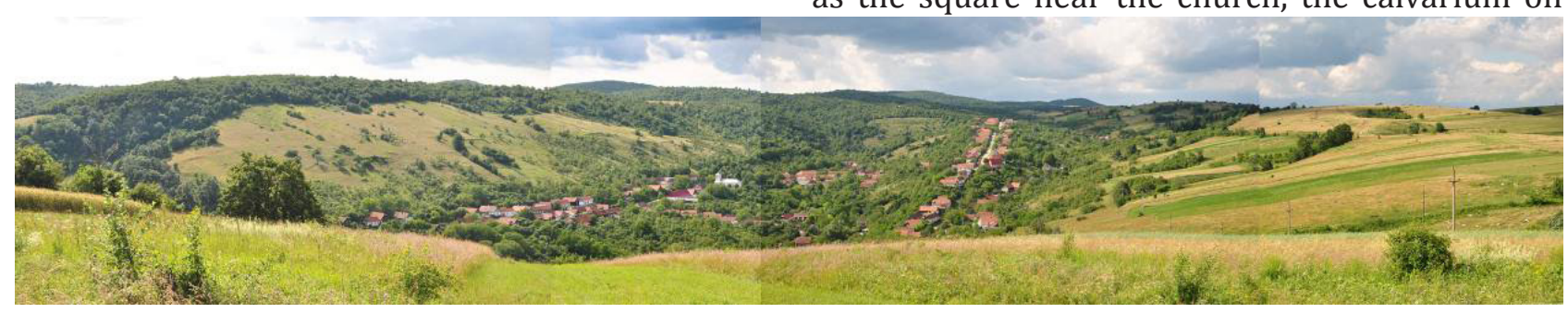

Fig. 4. Perspective to Garnic (original).
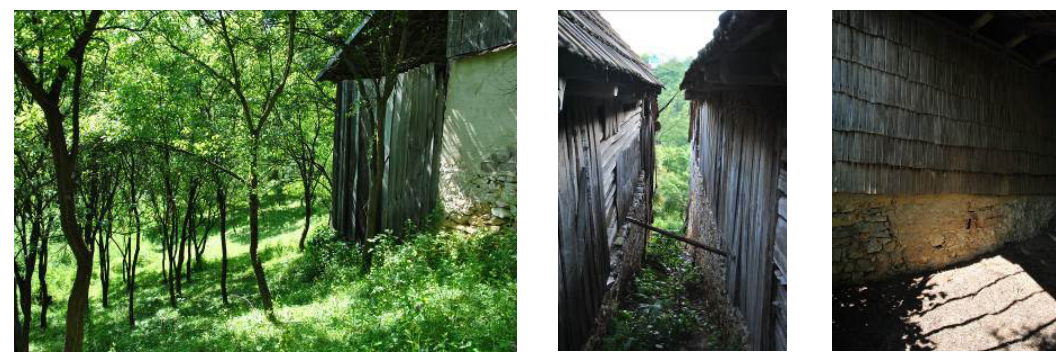

Fig. 5. Light in relation to architecture and landscape elements (original). 
the hill, the mills, the pocket on the creek where animals and people gather to drink water, proving the very strong relation between nature, man and landscape. The village is organized around the gardens with orchards and meadows, places which reveal a great atmosphere. The village centre is located between the upper and the lower part of the settlement, a very complex place where the topography of the terrain and the roads generate several gathering places, such as the mill on the creek, the school and the small church square, where the village celebrations take place. The church connects the people, the Earth and the Sky (Norberg-Schultz, 1980).

The agricultural landscape is very well organized because the large hilly landscape of Garnic is great for agriculture, and meanwhile, since the core of the valley is protected, it is ideal for plum and apple orchards combined with meadows. The area which is now the agricultural terrain faces south-west, where the slopes are not very harsh, and the marriage of the Sun with the land is very productive. Because of the generous boundaries and the generosity of the land, the individual agricultural lands are quite specialized, mixed usage for plots being quite rare (Fig. 6). At landscape scale, the land mosaic is very diverse: on the north-east slopes (facing south-west) there is agricultural land, meadows and pastures while the valley, the core of the village, is covered with orchards (Fig.7.3).

Animal grazing is very well organized at Garnic and is usually done in surrounded places or in orchards, this practice fertilizing the land and stimulating the biodiversity of the area. When the food from a garden or a pasture is almost finished, the location changes and thus the nature and the quality of the pasture are once again restored.

\section{Morphology and architecture}

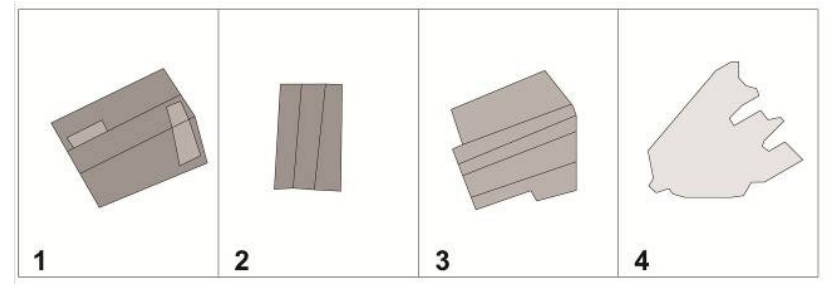

Fig. 6. Plot structure and organization (1) orchards and small vegetable gardens; (2) orchards (sometimes combined with meadows); (3) agricultural land facing south-west (4) meadows with forest boundary (original).
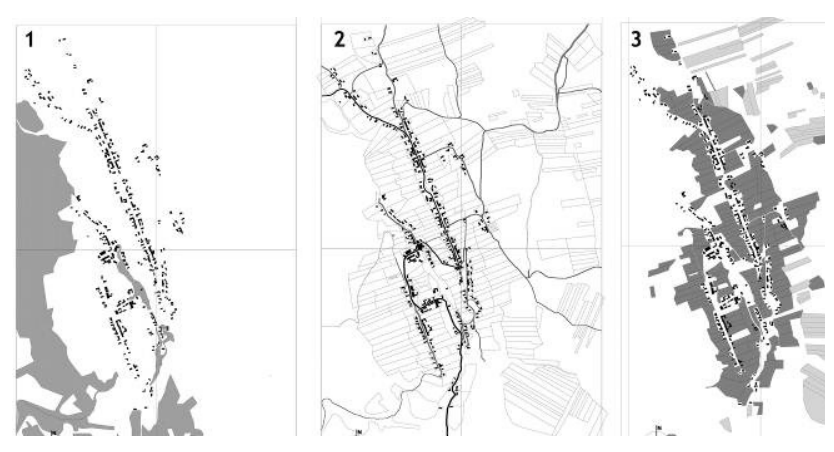

Fig. 7 Garnic (1) the dense forest on the west, opening to the east; (2) penetrations and roads; (3) land use mosaic, agriculture, meadows, pastures and orchards (original).

4.1. Settlement morphology. The colonization of Banat, developed by the Habsburg monarchy as a general pattern was part of an Absolutist, Baroque understanding of the Universe. In this historical and cultural context, the two main institutions which guided the society were the Church and the monarchy. This inner pattern of the Western cultures (which included the Czechs) was embodied in the morphology of the colonial (predefined or the systematized) settlements in/ from the Banat region. The families which formed the society were aligned linearly in a methodical,
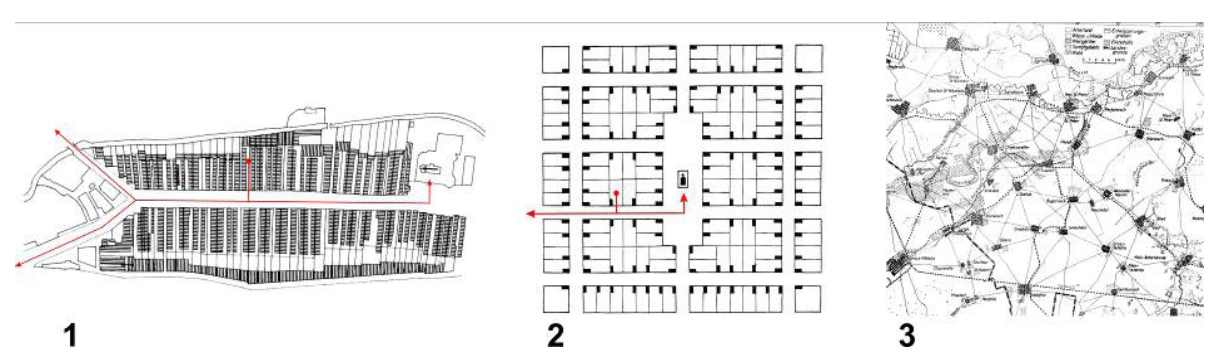

Fig. 8. (1) Oslip, Burgerland, typical occidental street pattern ; (2).Debeljaca, Serbian Banat, original village plan; (3) Banat settlement network (The Roman-Catholic Bishop in Timisoara archives). 
rhythmic path: one direction lead to the Church and the other lead to the macro network of roads which joined the other settlements together. This whole network formed the Empire which was then administrated by the Crown in Vienna (Fig.8).

The actual settlement layout pattern and plots of the Czech villages were developed by military surveyors, fact which is also visible in the regular plot organization (Gecse, 2013), but because of the hilly terrain they had to adapt their predefined patterns to the topography. The street network of Ravensca coincides with the hilltop peaks where the centre square and the church lay at the crossroads (intersection) of four peaks (Fig. 9.1). It is interesting that this particular unusual hilltop position inverts the common relationships between earth and sky in valley villages. Here, the water stream is the spine on which the settlement is formed, and also the connection to the world, the embodiment of temporality and life. In the valleys, the sky is far above, guarded by the wild nature of the hills, and only the church receives a higher position, thus facilitating the link to the sky. In Ravensca, the inner circulations that coincide with the hilltop peaks continue on the outside peaks and form the circulation network to the outside world. Therefore, the hilltops have become the humanized nature (marked by sacred crosses) and the wooded valleys become the wild, the unknown, the place wherefrom the enemies come and where abstruse cultures live.

Here the church takes the central place (at the centre of the radial settlement structure), but also a lower more protected position, in comparison with the rest of the village. Near the church, there are some very old trees (Fagus sylvatica) guarding the central square since the Czech colonists first came in Ravensca. Those trees have a double significance. On the one hand the trees symbolize life and on the other hand they mean history and the changing of generations of the Ravensca community.

While in the valley villages the perspective is vertical, from the Earth to a mysterious and sacred Heaven, on the hilltop, the sky is very present, common and the perspective is horizontal. From our contemporary point of view, such a bird's eye perspective over the surroundings has to be exploited, so if we built a house there it would surely open to the panorama (Fig. 9.2). But the traditional society apparently felt different about this, and so they blocked their courtyard views towards the panorama in order to protect themselves from the wind and snow, but also in order to preserve the traditional inner courtyard and vertical relationship with the sky. Moreover, the street, which is limited by buildings, is relatively compact, so that the visual relationship is linear, along the street. The centre square occupies a lower position and was originally unbuilt, except for the church, which sits higher in the square level, so that the vertical direction is strengthened. The horizontally-framed visual relationship with the surroundings occurs towards the exterior of the village, in certain places during the itinerary through the settlement, behind or beyond the barn. In conclusion, during the journey through the village, the visual and the spatial directions are transformed from a horizontal, natural outdoor space to a linear street space and, finally, to a positive space with a vertical opening towards the sky. Meanwhile, the community is shrinking and many homesteads are disappearing, therefore increasingly more voids appear on the streets and within the community, fact which is starting to

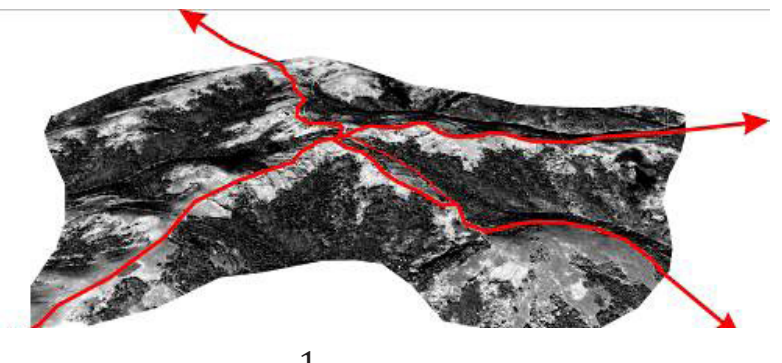

1

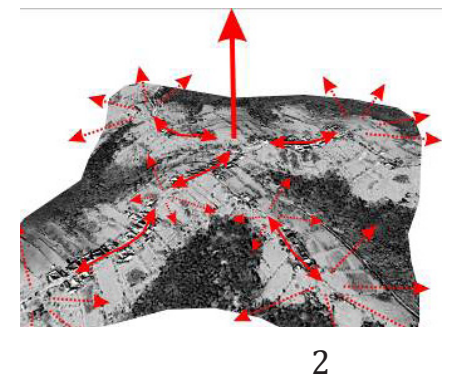

2

Fig. 9. Ravensca: (1) Hilltop circulations; (2) Spatial and visual directions (Google Earth). 
change back the colonist's linear space direction and to transform it into the original natural one.

Garnic, the second village of our case study, is placed on a lower terrain level than Ravensca (on a plateau, somewhere in-between hilltop and valley). It is formed from two main streets, one coming from a small hilltop peak and a lower one wriggling on the opposite hill. These two halves of the village are separated by a river which springs nearby. The church was built in the lower part of the village and on the Franciscan mapping it can be clearly seen that there was a square around it. It can also be observed that the current main square was an unbuilt space, probably serving in the past as a temporary commercial market, placed exactly on the river bank next to the bridge which connects the two parts of the village. It is interesting to see how, in time, the importance of these two squares has shifted. The church

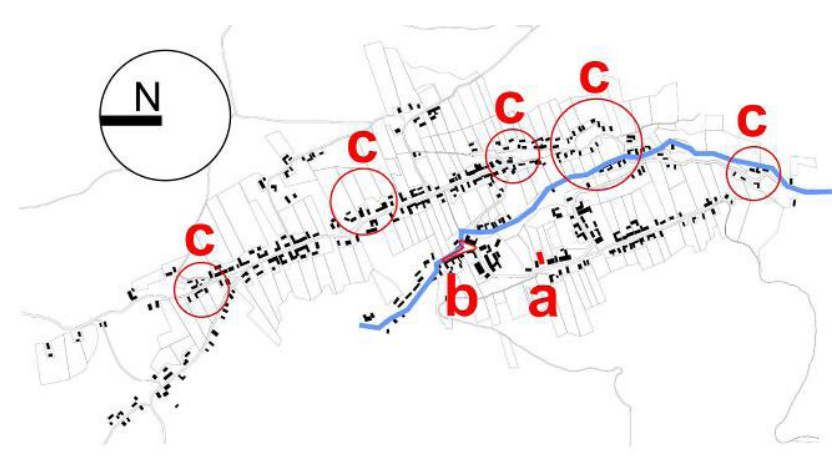

Fig. 10. Garnic-current morphology a. the church; b. the main square and market place; c. natural karst accidents that influence the village morphology (original). square has been occupied by buildings and the commercial market has become the new village centre, with the communist cultural hall (now the village bar) at its centre. The linear, uniform street pattern is now broken in many places because of the natural accidents occurring on karst terrain. Therefore, the usual perception is that many parts of the village sit organically on the terrain, where nature controls the street pattern (Fig.10).

4.2. Homesteads. The homestead and the colonial long and narrow plots lay well organized, perpendicular to the street. The relation between the community (the street) and the family (the homestead) was open and natural, through the gaps between the gabled house fronts. These gabled house fronts initially looked the same, but in time they became differently shaped and decorated, marking each family's individuality (Fig.11).

The homestead was also a linear sequence of functions, which formed the family universe. The family house lays street wards, with its gable facade, actually delineating the road, and succeeded in the back by the animal shelters. After that, there are the storages and finally the barn, which lays transversal on the plot, in many cases occupying the whole width of the plot. This building separates the homestead from the backyard and the cultivated land. In Ravensca and Garnic we can find this original colonists' typology, but also the subsequent phases of the homestead "evolution" as an embodiment of the inner human transformations. One example is the relationship of the homestead (the family) to the street (the
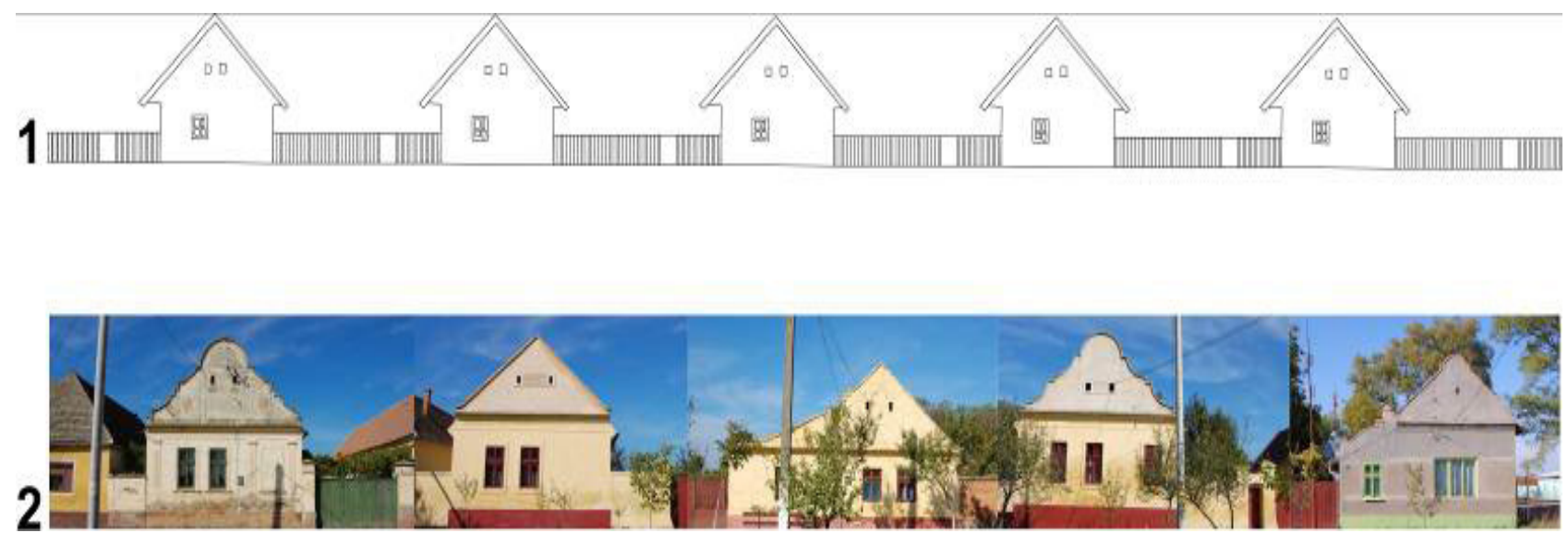

Fig. 11. (1) Facades of the Theresian colonist house; (2) Individualized colonist gabled facades (original). 
community) and its evolution. As said, the original colonists' settlement had the houses laid perpendicularly to the streets, while the entrance to the family universe and the exit to the community were linear, natural, through the family courtyard and through a porch to the street fence between the houses. Gradually, as the society evolved towards modernity, man became more and more separated from the universe and started to not feel like an open part of the community anymore. For this reason, the homestead became closed to the street, through the construction of the house parallel to the road and by occupying the whole width of the plot. This was achieved by extending the old house in an "L" shape or by reconstructing the house in the new way. Thus the house becomes a barrier between the street and the courtyard and its crossing can only be done through a big gate and gangway. The visual relationship between the family and the community is now possible only from the inside, through the windows, protected by curtains.

Another aspect is the relation of the house with the courtyard. The presence of the veranda at the colonists' houses is a controversial matter, even for the older Swabian colonial houses. The fact is that the original houses of the colonists did not have any veranda. There are two different theories explaining the occurrence of the veranda in Swabian colonists' houses: one is that there was a natural evolution from the protective cornice which in time grew to a veranda (which is not plausible in the case of Czech houses, because the original ones did not have such a cornice) or that the veranda was imported from the local (Serbian and Romanian) cultures (Roth, 1988). Apart from its functional role, the veranda is also an intermediate space between the interior

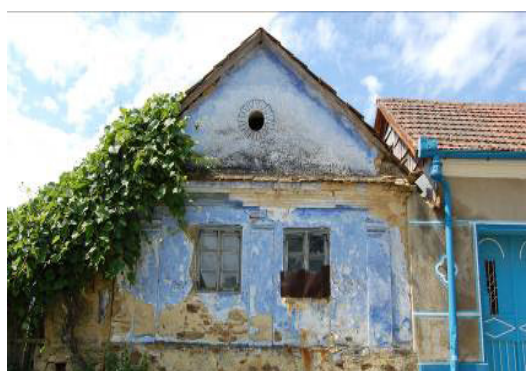

1

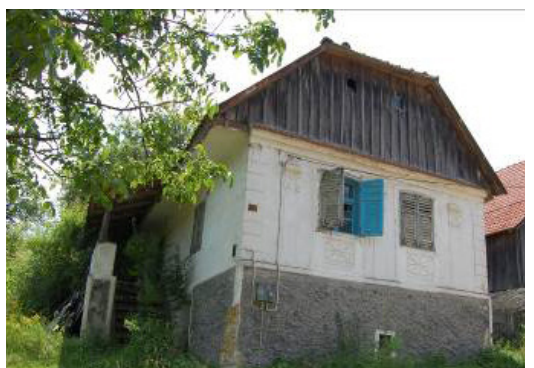

2

Fig. 12. (1) Ravensca no. 14; (2) Garnic no. 106.

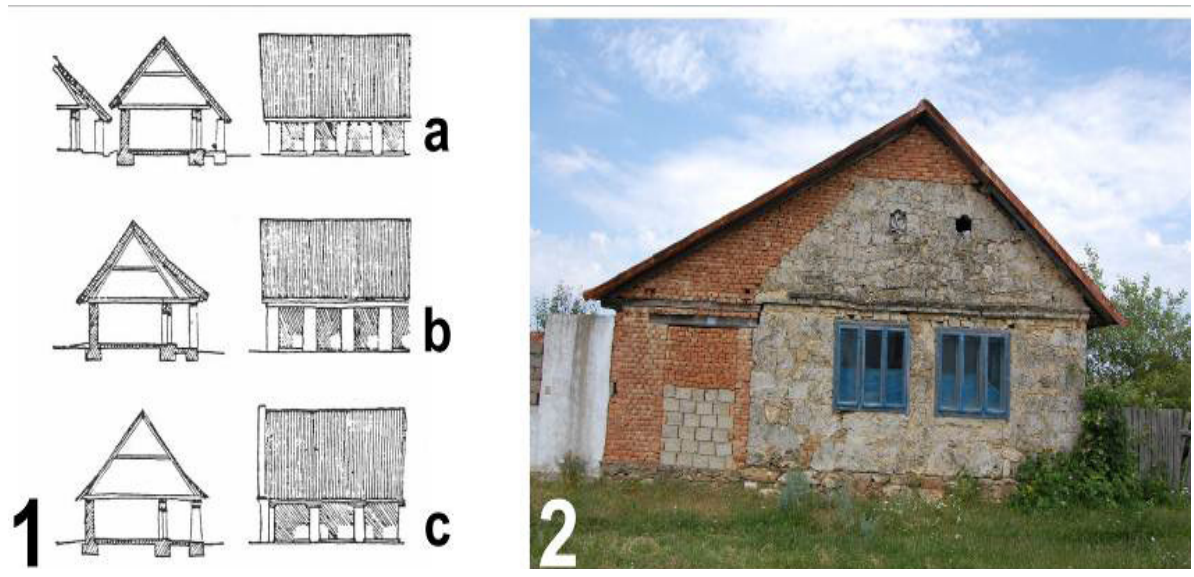

Fig. 13. (1) Evolution of the veranda (Roth, 1988); (2) Ravensca example (original). 
and the exterior, through which a gradual and soft passing is realized. It is a space where you are simultaneously inside and outside. We could imagine that one possible explanation for its original absence was the inner feeling of a colonist who is taken to a foreign place to live. Naturally, he could not feel close to this new environment from the very beginning, like the native Romanian and Serbian cultures, which used such spaces. First, the roof was continued without transforming the geometry of the roof truss and of the gable front facade. This type of solution can be seen in Ravensca at no. 14 (Fig.12). In Garnic, the solution was different and original: they only continued the posterior part of the house roof, so the gable front facade remained unmodified and a partial posterior veranda resulted. This solution was widely used in Garnic and can be defined as a local brand. The next step was to transform the roof truss, in order to obtain a larger veranda, and the contemporary tendency is to close back the house to the courtyard, by closing the veranda with walls and windows. These last two phases of the veranda's evolution can be clearly seen in the Ravensca no.17 façade (Fig.13).

\section{CONCLUSION}

Even if the two villages have a common history and culture, in time they have each developed their own Genius Loci. Because cultural values and the character of a society change in time the landscape is under continuous transformation (Haines-Young et. al. 2007). This type of change has been occurring throughout the entire history of mankind but by the (interdisciplinary) understanding of Genius Loci, the community can modernize without losing its identity. The phenomenological analysis used in this article for detailing only few elements of the local heritage could be extended and used in landscape documenting (Wascher, 2005) and drawing landscape, urban and architectural regulations for the two villages. Besides the quantity criteria such as: plot dimension, terrain occupation percentage, building height, street alignments, house orientation, materiality, one could also introduce more subtle criteria such as: visual relations, the village profile, the profile of the street facades, land mosaics, agriculture techniques, plot limits and circulation in relation to landscape. Therefore, the modernization of the village should be done in knowledge of the causes and effects that generated the Genius Loci.

Acknowledgement. This work was partially supported by the strategic grant POSDRU/159/1.5 /S/137070 (2014) of the Ministry of National Education, Romania, co-financed by the European Social Fund - Investing in People, within the Sectoral Operational Programme Human Resources Development 2007-2013.

\section{REFERENCES}

1. Baldock D, Beaufoy G, Dark J (1994). The Nature of Farming. Low intensity Farming Systems in Nine European Countries. Institute for European Environmental Policy, London.

2. Blaga L (1969). Trilogia culturii, (The trilogy of culture). Ed. Pentru Literatură Universală, Bucharest.

3. CEMAT- $80^{\text {th }}$ meeting of the Commitee of Senior Oficials of European Conference of Ministers responsible for Regional/ Spatial Planning (2003). European Rural Heritage Observation Guide- CEMAT, Budapest.

4. Eliade M (1995). Sacrul şi profanul (Sacred and the Profane). Ed. Humanitas, Bucharest.

5. Eliade M (2011). Mitul Eternei Reintoarceri, (Them Myth of The Eternal Return). Ed. Univers Enciclopedic, Bucharest.

6. Gecse D (2013). Historie českých komunít v Rumunsku (The history of Czech community in Romania), Prague.

7. Haines-Young R, Langanke T, Potschin M (2007). Landscape character as a framework for the assessment of environmental change. Use of Landscape Science for the Assessment of Environmental Security, 159-168, Springer, Netherlands.

8. Herzog F (1998), Streuobst: a traditional agroforestry system as a model for agroforestry development in temperate Europe. Agroforestry Systems 42:61-80, Kluwer Academic Publishers, Netherlands.

9. James A, LaGro Jr. (2008). Site analysis. A contextual approach to sustainable land planning and site design. John Wiley \& Sons, INC., New Jersey.

10. Jiven G, Larkham PJ (2003). Sense of Place, Authenticity and Character: A Commentary. Journal of Urban Design 8(1):67-81.

11. Lowental D (1979). Environmental Perception: Preserving the Past. Progress in Human Geography, 3(4):549-559.

12. McHarg IL (1992). Design with nature, John Wiley \& Sons, INC, New Jersey.

13. Norberg-Schulz C (1980). Genius Loci: Towards a Phenomenology of Architecture. New York, Rizzoli.

14. Norberg-Schulz C (1986). The Architecture of Unity. In Architectural Education in the Islamic World, edited by Ahmet Evin. Singapore: Concept Media/Aga Khan Award for Architecture. 
15. O'Donnell PM (2008). Urban Cultural Landscapes \& the Spirit of Place, ICOMOS, Quebec.

16. Roth E (1988). Die planmassig angelegten Siedlungen im Deutsch-Banater Militargrenzbezirk. 1765-1821, R. Oldenbourg.

17. Verscuure-Stuip GA (2009). Long Live the Genius Loci- Research to the Embedding of Urban and Landscape Architectural Designs to the Context for new Transformations. The $4^{\text {th }}$ International Conference of the International Forum on Urbanism (IFoU), Amsterdam/ Delft.
18. Wascher DM (ed). (2005). European Landscape Character Areas - Typologies, Cartography and Indicators for the Assessment of Sustainable Landscapes. Final Project Report as deliverable from the EU's Accompanying Measure project European Landscape Character Assessment Initiative (ELCAI), funded under the 5th Framework Programme on Energy, Environment and Sustainable Development (4.2.2), $\mathrm{x}+150 \mathrm{pp}$.

19. Workman SW, Allen SC, Demers C (2014). The Practice and potential of Agroforestry in the Southeastern United States. Agroforestry Systems, 59, pp.73-83, Kluwer Academic Publishers, Netherlands. 